\title{
Peran Pemikiran Heuristik pada Hubungan Persepsi Sosial dengan Munculnya Sikap terhadap Ide Penegakkan Khilafah Islamiyah di Indonesia
}

\author{
Ros Mayasari \\ IAIN Kendari \\ mayagayo@yahoo.com
}

\begin{abstract}
The spread of the idea of application of Khilafah Islamiyah (Islamic Caliphate) emerges zealously over the last few years. This phenomenon occurs especially among the younger generation. Through a quantitative approach, this research examines the theoretical model of the relationship between the need to reject the uncertainty, the social perception of the reality of a society and democratic practices, bias heuristic thinking and the attitude towards the idea of the application of khilafah Islamiyah in Indonesia. Data processed by regression analysis with 245 respondents. Based on the test results of the regression analysis, theoretical models did not fit with the data. Researchers propose a new theoretical model that does not involve variable need of uncertainty avoidance. The 'biasheuristic variable' thinking proves to be an alternative mediator variable in the relationship between social perception of reality of a society, and democratic emergence and attitudes toward the idea of khilafah Islamiyah. For further research, suggested using SEM analysis. Researchers recommended the need to develop and construct the critical thinking among the younger generation, so they become more critical in addressing ideas tend to be radical
\end{abstract}

\begin{abstract}
Abstrak
Penyebaran ide tentang penerapan Khilafah Islamiyah sangat gencar dilakukan beberapa tahun terakhir, terutama pada generasi muda. Melalui pendekatan kuantitatif, penelitian ini menguji model teoritis hubungan antara kebutuhan untuk menolak ketidakpastian, persepsi sosial terhadap realitas masyarakat dan praktek demokrasi, bias heuristic thinking, dengan sikap terhadap ide penerapan Khilafah Islamiyah di Indonesia. Data diolah dengan analisis regresi dengan 245 responden. Berdasarkan hasil uji analisis regresi, model teoritik tidak fit dengan data. Peneliti mengajukan model teoritik baru yang tidak melibatkan variable kebutuhan menolak ketidakpastian. Variabel bias heuristic thinking terbukti sebagai variabel mediator dalam hubungan antara persepsi terhadap kondisi social dengan munculnya sikap terhadap ide penegakkan Khilafah Islamiyah. Untuk penelitian selanjutnya, disarankan menggunakan analisis SEM. Peneliti merekomendasikan perlunya pengembangan berpikir kritis di kalangan generasi muda, agar lebih kritis dalam menyikapi ide-ide yang cenderung radikal.
\end{abstract}

Keywords; Attitudes; Perception; bias heuristic thinking; need of uncertainty avoidance; the Caliphate. 


\section{A. Pendahuluan}

Ide tentang penerapan Khilafah Islamiyah sangat gencar dilakukan beberapa tahun terakhir ini khususnya oleh Hizbut Tahrir Indonesia (HTI). HTI memandang gagasan nasionalisme dan konsep negara-bangsa sudah ketinggalan jaman dan bertentangan dengan nilai-nilai Islam.Sebagai gantinya, HTI mengusulkan sebuah ke-khalifah-an yang mencakup seluruh dunia, sebagai otoritas politik tunggal, bagi seluruh umat Islam di seluruh dunia.

Chusniyah menjelaskan polarisasi sikap Muslim di Indonesia terhadap ide penerapan KhilafahIslamiyahdi Indonesia berada dalam sebuah kontinum sikap yang bersifat bipolar. Mengikuti pendapat Unger, Chusniyah ${ }^{1}$ menjabarkan bahwa perbedaan antara 'kita' (Muslim yang setuju dengan KhilafahIslamiyah) dan 'mereka' (Muslim yang tidak setuju dengan KhilafahIslamiyah) merupakan masalah perbedaan 'degree' (derajat) sikap. Baik 'kita' maupun 'mereka', merupakan Muslim Indonesia.Oleh karena itu, penting untukmelihat fenomena sikap masyarakat muslim khususnya mahasiswa muslim terhadap ide penerapan KhilafahIslamiyah.

Terdapat sikap yang berbeda di antara mahasiswadalam menanggapi ide penerapan Khilafah Islamiyah di Indonesia.Oleh karena sikap adalah salah satu obyek dalam kajian psikologi, maka diperlukan kajian psikologis yang dapat menjelaskan faktor-faktor psikologis yang mempengaruhi sikap mahasiswa terhadap ide penerapan Khilafah Islamiyah di Indonesia. Penelitian ini difokuskan kepada pengaruh faktor psikologis yangterdiri dari persepsi sosial terhadap realitas masyarakat dan praktek demokrasi di Indonesia, kebutuhan untuk menolak ketidakpastian, dan bias heuristic thinking terhadap sikap mahasiswa tentang ide penerapanKhilafah Islamiyah di Indonesia.

Penelitian ini mendasarkan pengembangan model teoritik dengan berdasarkan teori tentang sikap dan pembentukannya, teori keterbatasan rasionalitas dari Kahneman ${ }^{2}$, teori persepsi dan kognisi sosial dan tentang

\footnotetext{
${ }^{1}$ Chusniyah, T. Model Sikap terhadap Penegakan Khilafah-Syariah di Indonesia, Jurnal Insan, Vol.14 No.2. 2012, 68

${ }^{2}$ Teori keterbatasan rasionalitas pertama kali ditulis oleh Kahneman dan Tversky di tahun 1974 untuk menjelaskan bahwa manusia pada akhirnya cenderung mengandalkan prinsip-prinsip heuristik untuk mengambil kesimpulan atau membuat keputusan yang cepat dan memuaskan.Kahneman, D. (2002). Maps of bounded rationality: A perspective on intuitive judgment and choice.
} 
kebutuhan untuk menolak ketidakpastianserta hasil penelitian Khairiri di tahun $2014^{3}$, Nurjannah pada tahun $2011^{4}$ dan Chusniyah di tahun 2011$2012^{5}$.

Sikap merupakan proses penilaian yang dilakukan seseorang terhadap suatu obyek (ide, orang dan lain-lain). Secara sederhana, sikap dimaknai sebagai evaluasi positif/suka/setuju atau evaluasi negatif/tidak suka/tidak setuju tentang obyek sikap.Sikap merupakan bentuk evaluasi perasaan mendukung atau tidak mendukung.Dengan demikian sikap terhadap ide penegakan Khilafah Islamiyah merupakan kecenderungan psikologis seseorang yang diekspresikan dengan mengevaluasi obyek tertentu dengan tingkat kesukaan atau ketidaksukaan atau tingkat persetujuan terhadap ide penegakan khilafah Islamiyah.

Penelitian Khairiri yang menunjukkan bahwa penyebarluasan idepenerapan Khilafah Islamiyah dilakukan melalui strategi pembingkaian (framing). Salah satu komponen yang penting dalam framing ini adalah dengan menyalahkan penyebaran nilai-nilai dan praktek Barat yang dianggap menjadi sebab kemunculan berbagai penyakit social seperti kemiskinan, pengangguran, kemandekan ekonomi, utang luar negri yang membengkak, kemorosotan moral dan lain-lain. Selanjutnya kelompok ini menawarkan Islam dalam bingkai khilafah sebagai satu-satunya jalan keluar untuk hal tersebut. Elemen pembingkaian ini kemudian disebut sebagai pembingkaian prognostic. Kemudian dilanjutkan dengan

http://www.nobelprize.org/nobel_prizes/economics/laureates/2002/kahnemann-

lecture.pdf. tanggal 10 Desember 2014

${ }^{3}$ Penelitian Khairiri dilakukan untuk penyelesaian tugas akhir di UIN Syarif Hidayatullah dengan pendekatan kualitatif dengan memotret gerakan dan strategi kaderisasi Hyarif Hidayatullah. Ahmad Khairiri,Gerakan Fundamentalisme di Perguruan Tinggi Islam (Studi pada Gerakan dan Strategi Kaderisasi HTI di Kampus UIN Syarif Hidayatullah Jakarta. Skripsi.(Jakarta: Program Sarjana UIN Syarif Hidayatullah, 2014)

${ }^{4}$ Nurjannah melakukan penelitian eksperimen untuk melihat pengaruh paparan sejumlah kasus sosial diikuti dengan paparan ajaran dakwah yang dimaknai tertentu (radikal atau moderat) pada sikap subyek terhadap radikalisme.Nurjannnah, Radikal vs Moderat: Atas Nama Dakwah, Amar Makruf Nahi Mungkar dan Jihad.(Yogyakarta: Aswaja Pressindo, 2013)

${ }^{5}$ Penelitian Chusniyah dilakukan dengan mixed method dengan sampel responden yang telah menjadi anggota kelompok tertentu yang mengusung ide perlunya sistem Negara diubah menjadi Khilafah Islamiyah dan mewancarai para tokoh organisasi tersebut termasuk Abu Bakar Baasyir. Penelitian ini kemudian dipublikasikan pada Jurnal Insan Volume 12 Nomor 4 tahun 2012

${ }^{6}$ Khairiri, A., Gerakan ... h.67 
menawarkan ajakan untuk bergerak setelah sedikit digambarkan tentang persoalan. Pembingkaian ini adalah tahap pembingkaian motivasi (motivation framing) yang sengaja dibentuk sebagai sebuah proses psikologi untuk bergerak.Selanjutnya, gagasan khilafah ini menjadi magnet yang kuat dalam pola pikir masyarakat, karena gagasan ini hadir satu paket dengan nilai-nilai Islam.

Di sisi lain, sikap terbentuk atau dipelajari melalui proses persepsi terhadap obyek tersebut. Hubungan yang positif atau negatif antara individu dengan obyek tertentu akan menimbulkan sikap tertentu pula dari individu terhadap obyek tersebut (Taylor, S.E., dkk. ${ }^{7}$, Myers, ${ }^{8}$ ). Dengan demikian sikap terhadap ide penegakan Khilafah Islamiyah di Indonesia berhubungan erat dengan persepsi yang terbangun melalui strategi framing yang dijelaskan di atas. Dengan demikian dapat disimpulkan persepsi seseorang terhadap kondisi sosial dan praktek demokrasi mempengaruhi sikap seseorang terhadap ide penegakkan Khilafah Islamiyah di Indonesia.

Persepsi terhadap kondisi sosial, terutama tentang penyebab kemunculan berbagai penyakit sosial seperti kemiskinan, pengangguran, kemandekan ekonomi, kemorosotan moral dan lain-lain membawa individu kepada kebutuhan akan strategi atau solusi untuk mengatasi keadaan sosial tersebut. Persepsi manusia merupakan proses kognitif. Sebagai sebuah proses kognitif, kemampuan pemrosesan kognitif manusia terbatas. Oleh karena pemrosesan kognitif manusia terbatas, maka pada suatu keadaan manusia menggunakan serangkaian jalan pintas kognitif. Proses berpikir heuristik merupakan salah satu jalan pintas kognitif manusia untuk memahami sesuatu.

Pada proses berpikir heuristik, kondisi individu cenderung menyederhanakan suatu peristiwa yang dialami. Penyederhanaan itu dilakukan dengan cara pertama representasi yaituindividu mengambil kesimpulan mengenai suatu gejala sosial hanya berdasarkan pada ciri-ciri tertentu. Kedua, framingaitu pengambilan kesimpulan berdasarkan pengalaman yang baru saja terjadi atau yang paling dialami.Ketiga, base rate fallacy yaitu pengambilan kesimpulan dengan cara melakukan generalisasi pada sekelompok individu berdasarkan perilaku individu lain. Keempat, keterbatasan informasi yang tersedia yaitu pengambilan

\footnotetext{
${ }^{7}$ Shelley E.Taylor, dkk., Psikologi...h.169

${ }^{8}$ David.G., Myers,Psikologi Sosial, terj. Aliyah Tusyani dan kawan-kawan., (Jakarta: Salemba Humanika, 2012), h.166
} 
kesimpulan berdasarkan informasi yang minim (Taylor, S.E. $\mathrm{dkk}^{9}$, dkk. Myers, ${ }^{10}$ ). Kadang-kadang cara pintas mental yang dapat membantu, namun dalam kasus lain mereka dapat menyebabkan kesalahan atau bias kognitif.

Bias kognitif adalah jenis kesalahan dalam pemikiran yang terjadi ketika orang sedang memproses dan menafsirkan informasi dunia di sekitarnya. Bias kognitif merupakan hasil usaha individu untuk menyederhanakan pengolahan informasi. Bias kognitif sering merupakan hasil dari upaya individu untuk menyederhanakan pengolahan informasi. Tekanan sosial, motivasi individu, emosi, dan batas kemampuan pikiran untuk memproses informasi juga dapat berkontribusi untuk bias ini.Bias ini tidak selalu semuanya buruk, namun para ahli psikologi percaya bahwa banyak dari bias ini melayani tujuan adaptif yang memungkinkan seseorang untuk mencapai keputusan dengan cepat. Hal ini dapat menjadi penting jika kita menghadapi situasi berbahaya atau mengancam.

Proses berpikir heuristic juga dapat terjadi oleh adanya kebutuhan untuk menolak ketidakpastian yang tinggi pada individu. Kebutuhan untuk menolak ketidakpastian merupakan kecenderungan individu kelompok untuk mencari sesuatu yang dikenal dan tidak ambigu. Apapun yang asing dianggap sebagai sumber ancaman, berbahaya danmemunculkan kecemasan akan ditolak. Sumber dari ketidakpastian ini meliputi segala yang asing, perbedaan pendapat, kompleksitas masalah, sesuatu yang baru, ambiguitas dan perubahan sosial (Wilson, dalam Chusniyah,). ${ }^{11}$ Chusniyah menjelaskan individu yang memiliki kebutuhan dasar untuk merasa pasti tentang dunia tempat mereka hidup, memiliki kebutuhan untuk menghilangkan ketidakpastiandengan mengelolanya secara kognitif sehingga ketidakpastian itu dapat ditoleransi. Untuk mengurangi ketidakpstian ini, individu akan menolak sesuatu yang tidak jelas, membuat kesimpulan secara prematur, menyukai hal yang sederhana dan stereotype. Individu yang menolak keidakpastian ini, resisten terhadap stimulus yang berfluktuasi, memilih dan memelihara satu solusi pada stimulus yang ambigu, menerima sikap yang rigid, hidup yang hitam putih serta mencari yang pasti-pasti. Individu ini juga akan tidak toleran terhadap ambiguitas, sehingga memilih konsepsi dikotomi dan kategorisasi yang kaku tentang norma budaya, seperti kuat-lemah, bersih-

\footnotetext{
${ }^{9}$ Shelley,E.Taylor,Psikologi ... h.175

${ }^{10}$ David.G. Myers, Psikologi .... h.166

${ }^{11}$ Chusniyah, T., Model.. h. 79
} 
kotor, moral-imoral, menolak persepsi yang ambigu dan enggan berfikir dalam perspektif probabilitas. Dalam upaya memenuhi kebutuhan untuk menolak ketidakpastian, mereka memandang dunia secara dikotomi seperti Islam-Kafir, Allah dan hukumnya, syari'ah, bersifat absolut, sebagai lawan dari aturan legal dan politik buatanmanusia: aturan Tuhan versus aturan manusia. ${ }^{12}$

Oleh karena itu, individu yang memiliki kebutuhan untuk menolak ketidakpastian yang tinggi dan menilai ketidakadilan dalam masyarakat serta kecewa dengan praktek demokrasi akan mudah dipengaruhi oleh framing yang dikembangkan oleh kalangan tertentu.Oleh karena itu, kebutuhan menolak ketidakpastiandapat mempengaruhi pembentukan sikap terhadap ide penegakkan Khilafah Islamiyah di Indonesia. Selanjutnya, faktorbias heuristic akan juga mempengaruhi hubungan antara kebutuhanmenolak ketidakpastian dengan sikap terhadap penerapanKhilafah Islamiyah. Hubungan antara persepsi sosial, kebutuhan menolak ketidakpastian dan bias heuristic thinkingdengan sikap terhadap ide penegakkan Khilafah Islamiyah dapat digambarkan dengan model di bawah ini

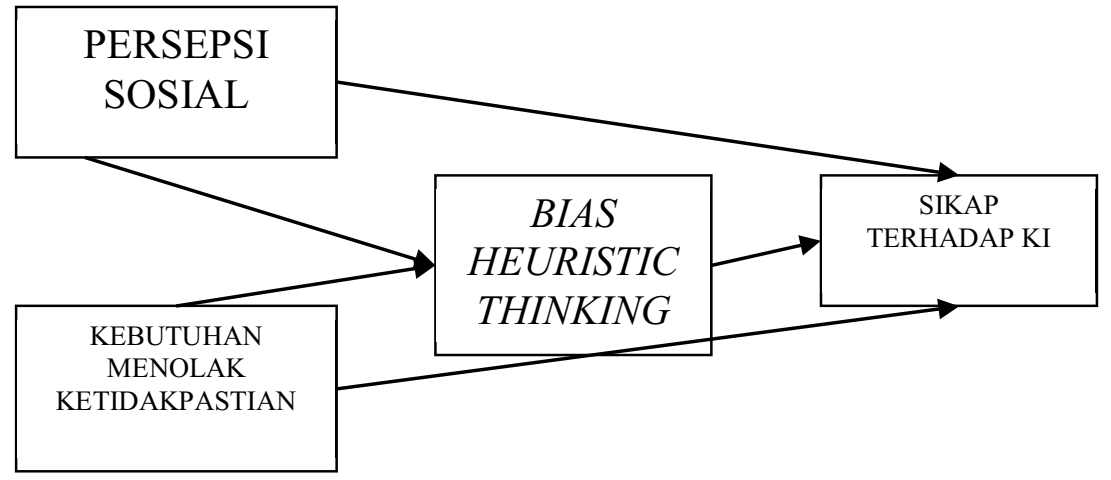

Gambar 1.Model Teoritik Hubungan Variabel Penelitian

Variabel bias heuristic thinking dalam model penelitian ini diduga kuat menjadi variabel mediator yang memperantai hubungan variabel persepsi sosial dan variabel kebutuhan menolak ketidakpastian dengan variabel sikap terhadap ide penegakkan Khilafah Islamiyah.

Penelitian ini bersifat kuantitatif.Populasi penelitian ini adalah mahasiswa IAIN Kendari dengan metode pengambilan sampel yang

\footnotetext{
${ }^{12}$ Chusniyah, Model... h.72
} 
digunakan adalah accidental sampling. Berdasarkan pemeriksaan kuesioner, tersisa 245 kuesioner yang selanjutnya dapat diolah.

Pengumpulan data tentang variabel-variabel dilakukan dengan penyebaran skala penelitian terhadap setiap responden dengan Skala Likert. Validitas dan reliabilitas alat ukur diperoleh dengan prosedur uji coba alat ukurdengan menggunakan sampel terpakai, yang dilakukan dengan pertimbangan bahwa sebagian besar alat ukur yang digunakan pada penelitian ini adalah alat ukur yang telah diujicobakan dalam beberapa penelitian, bukan alat ukur yang sama sekali baru. Data item yang valid dan reliabel, diperoleh melalui perhitungan analisis item dengan program SPSS 16.

Variabel sikap terhadap ide penegakan Khilafah Islamiyah merupakan evaluasi individu untuk setuju atau tidak setuju terhadap pengubahan sistem demokrasi dengan sistem khilafah-syariahdi Indonesia, yang diukur dengan menggunakan skala penegakan khilafahsyariah yang disusun oleh Tutut Chusniyah. ${ }^{13}$ Skala ini merupakan skala Likert 4, dengan pilihan angka $1=$ sangat tidak setuju, sedang $4=$ sangat setuju terhadap pernyataan. Oleh karena sikap bukan posisi yang netral, pengukurannya pun harus dapat mengukur sikap yang jelas, setuju atau tidak setuju. Contoh skala:" sistem negara demokrasi di Indonesia harus diubah menjadi sistem khilafah-syariah". Chusniyah ${ }^{14}$ melaporkan skala ini disusun setelah melalui proses elisitasi, terdiri dari dua item dan keduanya valid dengan nilai validitas 0,48 dan nilai reliabilitas $\alpha 0,66$.

Skala persepsi responden terhadap realitas sosial merupakan penilaian terhadap situasi sosial yang terdiri dari persepsi terhadap ketidakadilan, penyimpangan moral agama dan kekecewaan terhadap praktek demokrasi di Indonesia. Skala ini terdiri dari 5 item.Skala ini merupakan skala Likert 4, denganpilihan angka 1= sangat tidak setuju, sedang 4= sangat setuju terhadap pernyataan.Contoh skala:" Saya kecewa dengan cara pemerintah mengurus Negara ini." Skala ini disusun setelah melalui proses elisitasi, terdiri dari lima item. Setelah melakukan perhitungan validitas dan reliabilitas, ternyata seluruh item valid dengan menunjukkan koefisien reliabilitas berdasarkan Cronbach Alpha sebesar $\alpha$ 0,82

Untuk mengukur kebutuhan menolak ketidakpastian digunakan Skala Kebutuhan Menolak Ketidakpastian yang disusun oleh Chusniyah

\footnotetext{
${ }^{13}$ Chusniyah, T., Model ... h. 66

${ }^{14}$ Ibid
} 
yang terdiri Skala Keterbukaan terhadap Pengalaman, Skala Order dan Skala Intoleransi terhadap ambiguitas.Skala ini terdiri dari 15 item.Skala kemudian diujicobakan kembali. Berdasarkan hasil uji reliabilitas diperoleh koefisien reliabilitas berdasarkan Cronbach Alpha sebesar $\alpha$ 0,39 . Namun beberapa item ada yang tidak valid. Setelah mengeluarkan item tidak valid diperoleh koefisien reliabilitas berdasarkan Cronbach Alpha sebesar $\alpha 0,62$ dengan 7 item yang valid.

Untuk mengukur terjadinya bias dalam heuristic thinking responden terhadap pemecahan masalah yang dirasakan individu karena adanya persepsi tertentu terhadap keadaan sosial dan praktek demokrasi di Indonesia, disusun berdasarkan model pengukuran bias heurictic thinking yang dikembangkan oleh Marcin Sklad dan Rene F.W. Diekstra ${ }^{15}$. Sklad dan Diekstra menyusunHeuristic and Bias Scale (HBS) yang merupakan kuesioner yang dimaksudkan untuk menilai pola berpikir atau aturan/mekanisme mental seseorang yang cenderung digunakan dalam berbagai situasi, aktivitas dan masalah. Kuesioner yang disusun oleh peneliti ini mengkhususkan mengukur kesimpulan responden terhadap beberapa item pernyataan yang langsung terkait dengan keharusan dan kebutuhan untuk menerapkan Khilafah Islamiyah di Indonesia.

Kuesioner untuk mengukur bias heuristic thinking ini terdiri dari 7 item dengan skala Likert 4, dengan pilihan angka 1= sangat tidak setuju, sedang 4= sangat setuju terhadap pernyataan.Contoh item skala: " Alquran surat Al-Maidah ayat 44 menyatakan: "Siapa yang tidak menentukan hukum dengan apa yang diturunkan Allah adalah kafir. Jadi, posisi muslim yang tidak mendukung khilafah Islamiyah sama dengan posisi orang kafir.'Berdasarkan hasil uji reliabilitas diperoleh koefisien reliabilitas berdasarkan Cronbach Alpha sebesar a 0,86 dan semua item dinyatakan valid.

\section{B. Gambaran Sikap, Persepsi dan Bias Heuristic Thinking}

Responden sebagian besar berasal dari Fakultas Tarbiyah dan Ilmu Pendidikan dan berada pada semester II dan IV. Asal sekolah responden sebelum menjadi mahasiswa IAIN Kendari sebagian besar berasal dari sekolah menengah umum.Analisis statistik deskriptif dimaksudkanuntuk mengetahuidistribusi frekuensi jawabandarihasil kuesioner meliputi nilai minimum, nilai maksimun, mean dan standar deviasi.

\footnotetext{
${ }^{15}$ Marcin Sklad, \&Rene F.W. Diekstra,The development of the heuristic and biases scale (HBS), Procedia Social and Behavioral Sciences, 112 (2014) 710-718
} 
1. Sikap Responden terhadap Ide Penegakkan Khilafah Islamiyah di Indonesia

Hasil analisis deskriptif, menunjukkan bahwa 59,5\% responden mendukung atau setuju terhadap item yang menanyakan sikap responden terhadap ide penegakkan khilafah Islamiyah dengan kategori setuju dan sangat setuju. Selanjutnya pada pernyataan "Indonesia akan menjadi lebih baik dengan menjadi bagian dari khilafah-Islamiyah", menunjukkan $73,8 \%$ responden menyetujui item tersebut dengan kategori setuju dan sangat setuju.

Ditinjau dari latar belakang pendidikan responden, rata-rata skor Sikap terhadap Penegakkan Khilafah Islamiyah responden yang berasal dari SMK paling tinggi $(6,22)$ berturut-turut daripada responden yang berasal dari SMA $(5,88)$, Pondok Pesantren $(5,79)$ dan Madrasah Aliyah $(5,70)$. Namun, perbedaan rata-rata ini tidak signifikan berdasarkan hasil uji Oneway ANOVA. Hanya saja data tentang latar belakang sekolah hanya diolah dari 217 responden, oleh karena hanya sejumlah itu yang mengisi latar belakang sekolah pada kuesioner.Oleh karena itu, diduga pengolahan data tentang latar belakang ini tidak dapat maksimal dilakukan dalam perhitungan statistik untuk menguji perbedaan Sikap responden terhadap ide penegakkan Khilafah Islamiyah berdasarkan latar belakang pendidikan responden sebelum masuk di IAIN Kendari.

Perbedaan Sikap antara responden yang berasal dari madrasah dan sekolah umum terhadap ide penegakkan Khilafah Islamiyah, terjadi karena responden yang berasal dari madrasah (MA dan Pondok Pesantren) dibekali pengetahuan agama yang lebih banyak dan luas daripada responden yang berasal dari SMA dan SMK. Di SMA ataupun SMK, pengetahuan agama Islam hanya diajarkan pada satu mata pelajaran yaitu Pendidikan Agama Islam (PAI) dan pembelajaran PAI pada umumnya hanya satu kali diajarkan dalam seminggu. Di madrasah, siswa diajarkan tentang ajaran Islam melalui beberapa mata pelajaran (seperti Alquran Hadis, Sejarah Islam, Fiqh). Misalnya pengetahuan tentang hubungan Negara dan Islam dan adanya multi tafsir dalam memahami Islam sangat mungkin tidak diperoleh responden yang berasal dari SMA dan SMK. Perbedaan pengetahuan ini menjadi sebab perbedaan responden dalam menyikapi ide tentang penegakkan Khilafah Islamiyah di Indonesia.

2. Persepsi responden terhadap keadaan sosial di Indonesia dan praktek demokrasi 
Berdasarkan analisis deskripsi, ditemukan bahwa responden merasa kecewa dengan keadaan masyarakat dan pengelolaan Negara ini. Tingkat persepsi responden tersebut dapat dilihat pada Table 1 berikut ini.

Tabel 1. Kategorisasi Variabel Persepsi Responden

\begin{tabular}{|c|l|c|c|l|}
\hline No & Kategori & Interval & Frekuensi & Persentase \\
\hline 1 & Sangat Baik & $5-8$ & 10 & $3,2 \%$ \\
\hline 2 & Baik & $9-12$ & 52 & $22,1 \%$ \\
\hline 3 & Buruk & $13-16$ & 103 & $42,1 \%$ \\
\hline 4 & SangatBuruk & $17-20$ & 80 & $32,6 \%$ \\
\hline \multicolumn{2}{|r|}{ Jumlah } & 245 & $100 \%$ \\
\hline
\end{tabular}

Tabel 1 menunjukkan bahwa responden lebih banyak yang menilai bahwa ajaran Islam tidak diamalkan dalam kehidupan bermasyarakat dan pengelolaan Negara ini dilakukan dengan buruk dan menilai keterpurukan bangsa ini karena praktek demokrasi. Nilai rata-rata persepsi responden adalah 14,85 yang artinya responden mempersepsikan secara negative terhadap kondisi masyarakat dan pengelolaan Negara. Persepsi yang negative terhadap kondisi masyarakat dan pengelolaan Negara muncul karena responden dapat melihat sendiri kenyataan masyarakat di lingkungan sekitarnya dan pengalaman kehidupan mereka sendiri. Responden ada yang menyatakan bagaimana kesulitan yang dirasakan ketika harus membiayai kuliahnya sendiri karena orang tua tidak sanggup membiayainya. Orang tua yang hanya mengandalkan hasil kebun untuk memenuhi kebutuhan mereka sehari-hari. Di sisi lain responden melihat melalui media massa, orang begitu gampang mendapat uang misalnya karena korupsi, namun begitu mudah untuk mendapatkan keringanan hukuman ketika sudah dipenjara. Situasi seperti inilah yang membuat responden menganggap Negara ini tidak dikelola dengan baik

3. Kebutuhan Menolak Ketidakpastian Responden

Kebutuhan untuk menolak ketidakpastian merupakan kecenderungan individu kelompok untuk mencari sesuatu yang dikenal dan tidak ambigu. Tingkat kebutuhan menolak ketidakpastian reponden secara umum dapat dilihat pada Table 2 berikut ini. 
Peran Pemißiran Heuristikpada Hu6ungan Persepsi Sosial dengan Munculnya Sikap terhadap Ide Penegakkan Khilafah Islamiyah di Indonesia

Tabel 2. Kategorisasi Variabel Kebutuhan

Menolak Ketidakpastian Responden

\begin{tabular}{|l|l|c|c|c|}
\hline No & Kategori & Interval & Frekuensi & Persentase \\
\hline 1 & Sangat rendah & $12-16$ & 8 & $3,3 \%$ \\
\hline 2 & Rendah & $17-20$ & 60 & $24,5 \%$ \\
\hline 3 & Tinggi & $21-24$ & 137 & $55,9 \%$ \\
\hline 4 & Sangat tinggi & $25-28$ & 40 & $16,3 \%$ \\
\hline \multicolumn{2}{|c|}{ Jumlah } & 245 & $100 \%$ \\
\hline
\end{tabular}

Tabel 2 menunjukkan bahwa kebutuhan menolak responden sekitar $70 \%$ berada pada kategori tinggi dan sangat tinggi. Tingkat kebutuhan menolak responden juga dapat dilihat dari nilairerata pada variabel kebutuhan menolak ketidakpastian yaitu 21,95 yang berarti dikategorikan tinggi. Artinya responden membutuhkan situasi yang jelas dan tidak ambigu.

Responden sebagian besar merasakan ketidaknyamanan dalam situasi yang tidak jelas.Responden dikategorikan sebagai kelompok remaja akhir. Salah satu karakteristik yang paling menonjol pada tahap perkembangan remaja akhir ini adalah menilai kehidupan sebagaimana yang diinginkannya. Kelompok usia ini pada umumnya menginginkan jawaban yang pasti untuk segera mengatasi kegelisahan dari munculnya pertanyaan-pertanyaan dalam menghadapi kehidupan ini. Misalnya seorang responden menjelaskan bingung mengapa seorang muslim tidak setuju adanya Negara Islam padahal dia muslim. Kebingungan itu segera teratasi apabila dijelaskan bahwa orang tersebut tidak muslim lagi (kafir). Jawaban-jawaban seperti ini segera bisa memenuhi kebutuhannnya untuk menolak ketidakpastian. Hal ini juga berarti toleransi responden kepada situasi yang tidak pasti, cenderung rendah.

4. Bias Heuristic Responden terhadap Khilafah Islamiyah

Pemikiran heuristik merupakan proses pengambilan kesimpulan atau keputusan secara cepat berdasarkan data yang tidak lengkap, sehingga seringkali memunculkan bias dalam mengambil kesmpulan atau memecahkan masalah. Tingkat bias heuristic thinkingresponden terhadap ide Khilafah Islamiyah reeponden secara umum dapat dilihat pada Table 3 berikut ini. 
Tabel 3. Kategorisasi Variabel Bias heuristic thinking Responden

\begin{tabular}{|l|l|c|c|l|}
\hline No & Kategori & Interval & Frekuensi & Persentase \\
\hline 1 & Sangat rendah & $11-14$ & 36 & $14,7 \%$ \\
\hline 2 & Rendah & $15-18$ & 70 & $28,4 \%$ \\
\hline 3 & Tinggi & $19-23$ & 73 & $29,, 9 \%$ \\
\hline 4 & Sangat tinggi & $24-28$ & 40 & $27 \%$ \\
\hline \multicolumn{3}{|c|}{ Jumlah } & 245 & $100 \%$ \\
\hline
\end{tabular}

Tabel 3 menunjukkan bahwa bias heuristic thinking responden sekitar 50\% berada pada kategori tinggi dan sangat tinggi. Tingkat bias heuristic thinking responden juga dapat dilihat dari nilai rerata pada variabel bias heuristic thinking yaitu 19,71 yang berarti dikategorikan tinggi. Artinya responden cenderung melakukan pemikiran heuristik yang cenderung bias terhadap pemecahan masalah yang ditawarkan oleh ide penegakkan Khilafah Islamiyah. Responden cenderung menyederhanakan suatu peristiwa yang dialami dengan hanya berdasarkan pada ciri-ciri tertentu, dengan berdasarkan pengalaman yang baru saja terjadi atau yang paling dialami dan cenderung melakukan pengambilan kesimpulan dengan cara melakukan generalisasi. Misalnya, kemiskinan dan pengagguran yang dialami oleh sebagian masyarakat Indonesia hanya diklaim sebagai dampak dari penerapan sistem demokrasi di Indonesia. Oleh karena itu, diperlukan sebuah tata pemerintahan yang lebih dapat mensejahterakan masyarakat Indonesia. Tawaran ide penerapan Khilafah menjadi menarik karena ditawarkan dengan tafsir-tafsir agama dan sejarah keberhasilan Khilafah di masa lalu.

Penelitian ini juga menanyakan keikutsertaan respoden pada kegiatan atau aktivitas yang berhubungan dengan penyebaran atau sosialisasi penegakkan Khilafah Islamiyah yang dilakukan oleh organisasi tertentu dalam hal ini Hizbut Tahrir Kendari. Jawaban responden atas pertanyaan tersebut di atas dapat dilihat pada table 4 .

Tabel 4.Keikutsertaan responden pada kegiatan yang berhubungandengan aktivitas sosialisasi ide penegakkan Khilafah Islamiyah $(\mathrm{N}=235)$

\begin{tabular}{|l|c|}
\hline \multicolumn{1}{|c|}{$\begin{array}{c}\text { Kecenderungan Mengikuti } \\
\text { Kegiatan }\end{array}$} & Prosentase \\
\hline Tidak berminat & 40,4 \\
\hline Berminat & 29,4 \\
\hline Pernah aktif & 12,8 \\
\hline Aktif & 17,4 \\
\hline
\end{tabular}

Data di tabel 4 diperoleh dari 235 responden, karena 10 responden tidak mengisi bagian ini.Walaupun, sebagian besar responden kecewa 
dengan pengelolaan Negara ini dan setuju terhadap ide penegakkan Khilafah Islamiyah di Indonesia, namun demikian tidak serta merta berminat pada kegiatan-kegiatan seperti diskusi terbatas, temu akbar atau pawai yang dilakukan oleh organisasi yang mengusung ide penegakan khilafah Islamiyah di Indonesia seperti HTI. Tampak 40,4\% tidak berminat dan $12,8 \%$ pernah aktif (artinya tidak lagi mengikuti kegiatan yang diselenggarakan oleh HTI).

Berdasarkan jawaban essay responden pada pertanyaan alasan responden ikut atau tidak ikut pada kegiatan yang berhubungan dengan sosialisasi ide penegakkan Khilafah, ditemukan alasan yang cukup beragam tentang alasan responden tidak berminat mengikuti kegiatan yang berhubungan dengan sosialisasi penegakkan Khilafah. Sejumlah alasan yang ditulis oleh responden yaitu pertama, responden tidak mempunyai waktu karena tugas-tugas kampus atau dengan aktivitas lain di luar kampus (seperti bekerja). Kedua, responden sudah memiliki pemahaman yang berbeda dengan ide penegakkan Khilafah. Responden ada yang menganggap ide tersebut terlalu keras dan bertentangan dengan demokrasi dan Pancasila. Responden juga menuliskan seharusnya yang dilakukan bukan menegakkan Khilafah tetapi melakukan perbaikan tentang pemahaman umat tentang Islam. Ketiga, responden tidak simpatik dengan cara-cara yang digunakan oleh organisasi atau teman-temannya yang mempropagandakan isu penegakkan Khilafah. Responden menuliskan tentang sikap arogan, merasa paling benar dan selalu mengatakan kafir kepada orang lain yang tak seide dengan isu penegakkan Khilafah, sebagai karakteristik teman-temannnya atau organisasi yang mengusung ide penegakkan Khilafah ini.

\section{Hubungan Persepsi Sosial, Bias Heuristic Thinking dan Sikap terhadapKhilafah Islamiyah}

Model teoritis yang telah dibangun pada tahap pertama digambarkan dalam sebuah diagram jalur, yang akan mempermudah untuk melihat hubungan-hubungan kausalitas yang ingin diuji. Anak panah yang lurus menunjukkan sebuah hubungan kausal yang langsung antara satu konstruksi dengan konstruksil ainnya. 


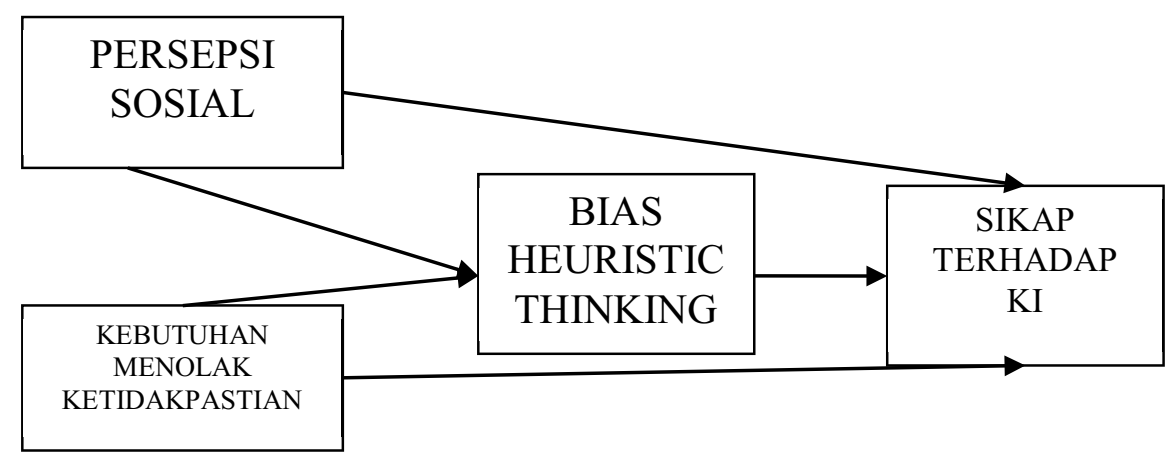

Gambar 2 Model Teoritik Penelitian

Berdasarkan analisisi regresi yang dilihat dari hasil out put SPSS, diperoleh beberapa analisis. Proporsi hipotetik/model yang diajukan tidak sepenuhnya bisa diterima, sebab berdasarkan pengujian, hanya koefisien jalur variabel Persepsi dengan variabel Bias heuristic thinkingdan jalur variabel bias heuristic thinking ke variabel Sikap yang secara statistik bermakna, sedangkan jalur yang melibatkan variabel kebutuhan menolak ketidakpastian tidak signifikan. Oleh karena itu, berdasarkan maka perlu dilakukan trimming ${ }^{16}$, yaitu mengeluarkan variabel kebutuhan menolak ketidakpastian dari model. Model yang diujiselanjutnya dapat dilihat pada gambar 2 berikut ini.

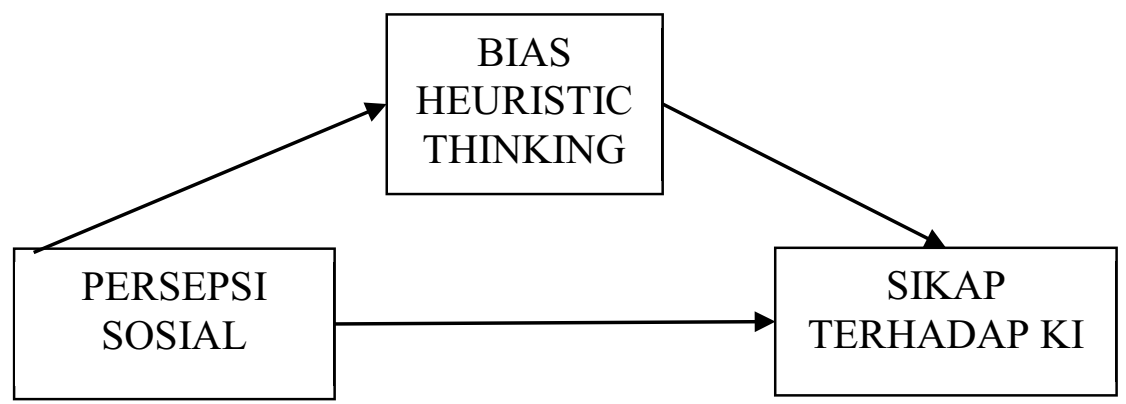

Gambar 2. Model Teoritik 2

\footnotetext{
${ }^{16}$ Theory trimming memungkinkan jalur yang non signifikan dibuang sehingga diperoleh model yang didukung oleh data empiris kecuali model tertentu yang didukung oleh data empiris sebagaimana penjelasan Abdul Razak Munir dalam Modul Aplikasi Analisis Jalur dengan SPSS versi 12. (Laboratorium Kompetensi Manajemen Jur Manajemen Fekon UNHAS)
} 
Secara simultan, pengaruh variabel Persepsi, dan Bias heuristic thinking terhadap Sikap adalah sebesar 0,545 (dibulatkan 55\%). Model simultan ini signifikan, dengan memperhatikan probablitas $\mathrm{F}$ sebesar 145,151 pada signifikan $0,000<0,05$. Setelah model simultan terbukti signifikan, maka dilakukan penelusuran jalur pengaruh parsial. Dari 2 variabel yang ditempatkan sebagai prediktor, seluruhnya memiliki nilai sig $<0,05$ sehingga dapat dikatakan bahwa seluruh prediktor secara parsial berpengaruh terhadap variabel Sikap.

Hasil analisis jalur menunjukkan bahwa Persepsi dapat bepengaruh langsung terhadap Sikap dan dapat juga berpengaruh tidak langsung yaitu melalui bias heuristic thinking lalu ke Sikap. Besarnya pengaruh langsung Persepsi terhadap Sikap adalah 0,134 dan pengaruh tidak langsung melalui bias heuristic thinking adalah 0,393 yang diperoleh dengan mengalikan koefisien tidak langsungnya dengan koefisien langsung yaitu $(0,605) \mathrm{X}$ $(0,650)$. Oleh karena koefisien hubungan langsung lebih kecil dari koefisien hubungan tidak langsung, maka dapat dikatakan bahwa hubungan yang sebenarnya adalah hubungan yang tidak langsung.

Untuk menganalisis apakah variabel bias heuristic thinkingdapat berperan sebagai mediator dalam model diatas dilakukan analisis regresi dengan strategi causal steps/bertahap. Pada analisis regresi pertama memasukan variable Persepsi sebagai variabel independent dan variabel bias heuristic thinking sebagai variabel dependen. Berikutnya dilakukan perhitungan regresi yang kedua, antara variabel Persepsi dan variabel Sikap, kemudian dilakukan regresi yang ketiga antar semua variabel.

Hasil analisisregresi pertama, menunjukkan bahwa persepsi berpengaruh langsung kevariable bias heuristic thinking ( $p$-value $<0,05$ ) dengan koefisien regresi0,605. Hasil regresi kedua,ditemukan bahwa Persepsi berpengaruh signifikan pada Sikap ( $p$-value $<0.05)$ dengan koefisien regresi 0,527.Pada Hasil regresi ketiga, ditemukan bahwa bias heuristic thinking berpengaruh signifikan pada Sikap, setelah mengontrol variabel Persepsi dengan koefisien regresi 0,650. Selanjutnya ditemukan juga direct effect pada regresi ketiga, dari Persepsi ke Sikap sebesar 0,134 yang lebih kecil dari 0,527 .

Pengaruh variabel Persepsi terhadapa Sikap berkurang, setelah mengontrol variabel mediator (bias heuristic thinking). Berdasarkan kriteria Baron dan Kenny maka hipotesis mediasional terdukung. Baron dan Kenny menjelaskan secara umum sebuah variabel merupakan variabel 
mediator yang efektif ketika dalam peranan total, porsi jalur peranan tidak langsung lebih besar dibandingkan dengan peranan langsung. ${ }^{17}$

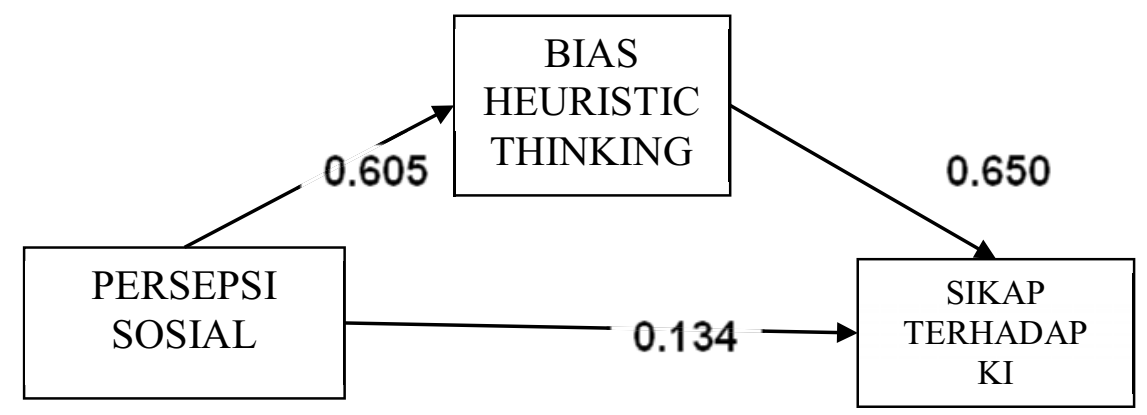

Gambar 4. Model Teoritik Hasil Penelitian

Berdasarkan hasil penelitian ini, model teoritik yang diterima adalah model teoritik yang menjelaskan bahwa Persepsi social terhadap realitas masyarakat dan praktek demokrasi di Indonesia mempengaruhi secara langsung dan juga tidak langsung terhadap pembentukan Sikap seseorang terhadap ide penegakkan Khilafah Islamiyah di Indonesia. Hubungan tidak langsungnya diperantai oleh bias heuristic thinking.

Bias heuristic thinking menjadi variabel mediator hubungan antara Persepsi dan Sikap terhadap ide penegakan Khilafah Islamiyah di Indonesia. Hubungan antara Persepsi terhadap praktek demokrasi dengan Sikap terhadap ide penegakan Khilafah Islamiyah tidak sederhana, tetapi bekerjanya bias heuristic thinking pada strategi pemikiran dapat mempengaruhi Sikap secara tidak langsung. Heuristicthinking adalah jalan pintas mental yang membantu mengaitkan informasi lingkungan dengan skema.Heuristicthinking mereduksi problem yang ambigu dan kompleks menjadi operasi penilaian yang lebih sederhana.

Tekanan efisiensi dalam mengambil kesimpulan terhadap realitas sosial yang dialami seseorang sering menyebabkan orang mengandalkan skema yang mereka punya untuk menangani aliran informasi yang kompleks dan cepat dalam dunia sosial. Individu membutuhkan cara untuk memilah informasi di sekitarnya. Individu perlu tahu mana struktur yang ada dalam memori jangka panjang yang cocok untuk memahami situasi social tertentu misalnya situasi masyarakat dan bangsa Indonesia. Tugas

\footnotetext{
${ }^{17}$ Baron, R.M., \& Kenny, D.A., . The moderator-mediator variable distinction in social psychological research: Conceptual, strategic, and statistical consideration. Journal of Personality and Social Psychology, 51, 1996, h.1178
} 

dengan Munculnya Sikap terhadap Ide Penegakkan Khilafah Islamiyah di Indonesia

ini (memilah dan mencocokan informasi dengan memori) menurut Tversky dan Kahneman sebagian besar dilakukan dengan cara menggunakan strategi pemikiran heuristic ${ }^{18}$.

Proses pemikiran heuristik berlangsung dalam berbagai tipe. Pertama dengan representative heuristic.Tipe representative heuristic ini menyandingkan informasi dalam lingkungan skema untuk menentukan kemungkinan apakah penyanding itu tepat atau tidak. ${ }^{19}$ Keterwakilan adalah penilaian tentang seberapa relevan A terhadap B. Relevansi yang tinggi menghasilkan perkiraan bahwa A mewakili atau berasal dari B. Representative heuristic karenanya membantu seseorang menentukan apakah orang atau kejadian adalah contoh dari skema tertentu. Misalnya jika ada pernyataan Indonesia adalah Negara dengan system pemerintahan yang menganut paham demokrasi. Kemiskinan dan penggagguran serta kejahatan masih terus berlangsung di Indonesia.Apakah system demokrasi yang digunakan menjadi penyebab semua ini? Dengan latar belakang pendidikan dan informasi yang ada pada seseorang, akan berusaha untuk melihat apakah pengggangguran, kemiskinan karena adanya karakter pribadi tertentu, adanya kompetensi kerja yang tidak memadai atau adanya hukum yang tidak tegas. Namun tugas ini membutuhkan waktu yang lama dan mungkin sumber informasi yang banyak dan variatif untuk menghasilkan penilaian tersebut mungkin tidak ada. Sehingga sangat memungkinkan untuk mendapatkan jawaban yang cepat, seseorang menjawab bahwa demokrasilah yang menjadi penyebab semuanya.

Representative heuristic juga menyebabkan individu mengkombinasikan informasi yang tidak sama karena informasi itu seolah-olah sama. Kesalahan terjadi ketika orang percaya bahwa beberapa kejadian yang tampaknya bergandengan akan terjadi secara bergandengan pula. ${ }^{20}$ Misalnya Alquran menyebutkan dalam surat Al-Maidah ayat 44: "Siapa yang tidak menentukan hukum dengan apa yang diturunkan Allah adalah kafir", menentukan hukum berdasarkan apa yang diturunkan Allah disamakan dengan menegakkan Khilafah Islamiyah. Oleh karena itu, dianggap posisi muslim yang tidak mendukung khilafah Islamiyah sama dengan posisi orang kafir.

\footnotetext{
${ }^{18}$ Amos Tversky dan Daniel Kahneman,Judgment Under Uncertainty:Heuristic and Biases, Science, New Series, Vol.185, No. 4157 (September, 27, 1974), h. 1129

${ }^{19}$ Ibid. h. 1130

${ }^{20}$ Taylor, dkk.Psikologi ... h.104
} 
Strategi pemikiran heuristik yang berikutnya adalahavailability heuristic. Availability heuristic adalah perkiraan seberapa sering atau seberapa mungkin kejadian peristiwa terjadi, didasarkan pada seberapa mudah atau cepatkah suatu asosiasi atau contoh muncul dipikiran. ${ }^{21}$ Misalnya tentang seberapa banyak undang-undang/aturan disusun berdasarkan hukum Islam. Individu yang memahami bahwa hukum Islam adalah segala ketentuan atau aturan yang berasal dari Alquran dan Hadis dan segala aturan yang tidak bertentangan dengan Alquran dan Hadis dapat lebih banyak menyebutkan bahwa aturan yang ada di Indonesia sesuai dengan hukum Islam. Namun, bagi yang mengasosiasikan hukum Islam adalah hanya hukum yang tertulis di Alquran dan hadist, tidakakan menemukan aturan/undang-undang yang disusun berdasarkan hukum Islam. Jadi kesimpulan seseorang akan sesuatu sangat berhubungan seberapa mudah dan cepat suatu asosiasi dimunculkan.

Tipe pemikiran heuristic selanjutnya adalah simulasi mental. Simulasi mental ini merupakan seberapa mudah skenario hipotesis disusun. ${ }^{22}$ Mensimulasikan bagaimana kejadian mungkin terjadi bisa memberi petunjuk tentang masa depan dengan membantu seseorang membayangkan kemungkinan di masa depan dan menyusun rencana untuk mewujudkannya. Hanya saja akan terjadi bias apabila orang terfokus tentang hasil di masa depan daripada memfokuskan untuk melakukan apa yang perlu dilakukan untuk mencapainya. Misalnya bias terjadi ketika orang begitu terpengaruh apabila disampaikan bahwa dengan perubahan sistem bernegara menjadi sistem Khilafah Islamiyah tersebut akan menciptakan kehidupan yang lebih baik, tidak ada lagi kemiskinan dan tidak ada lagi pengangguran. Tidak kemudian mencari tahu bagaimana strategi hal itu diwujudkan.

Seseorang tidak selalu memiliki waktu atau sumber daya untuk membandingkan semua informasi sebelum membuat pilihan, sehingga menggunakan heuristik untuk membantu mencapai keputusan dengan cepat dan efisien. Pada proses berpikir heuristik, kondisi individu cenderung menyederhanakan suatu peristiwa yang dialami. Penyederhanaan itu dilakukan dengan cara pertama representasi yaituindividu mengambil kesimpulan mengenai suatu gejala sosial hanya berdasarkan pada ciri-ciri tertentu, sehingga memungkinkan terjadinya bias kognitif.

\footnotetext{
${ }^{21}$ Cherry,K. Whatis a heuristic? http://psychology.about.com/od/hindex/g/heuristic.htm. ${ }^{22}$ Taylor, dkk, Psikologi ...h.106
} 
Penyederhanaan suatu kondisi di atas dapat dilihat dari sloganslogan yang diusung oleh organisasi yang menggagas ide penerapan Khilafah Islamiyah di Indonesia. Hizbut Tahrir dan sejumlah slogan seperti “Tidak Ada Islam tanpa Syari'at, Tidak Ada Syari'at tanpa Khilafah, Khilafah adalah Solusi, Saatnya Khilafah Memimpin Dunia, Demokrasi Nidlamul Kufri (Demokrasi Sistem Kufur), Indonesia Negara Kufur, Terapkan Syari'ah dan Khilafah, Kita Butuh Khilafah bukan Demokrasi dan sebagainya.

Bias kognitif adalah jenis kesalahan dalam pemikiran yang terjadi ketika orang sedang memproses dan menafsirkan informasi di dunia di sekitarnya. Tekanan sosial, motivasi individu, emosi, dan batas kemampuan pikiran untuk memproses informasi juga dapat berkontribusi untuk bias ini.Bias ini tidak selalu semuanya buruk, namun para ahli psikologi percaya bahwa banyak dari bias ini melayani tujuan adaptifyang memungkinkanseseorang untuk mencapai keputusan dengan cepat khususunya dalam situasi yang berbahaya atau mengancam. ${ }^{23}$

Dengan demikian, orang melakukan pemrosesan inferensial dengan cara heuristic dan cepat, sedangkan dalam kasus lain melakukannnya secara sistematis dan mendalam. Perbedaan pemrosesan ini penting untuk memahami sikap dan perubahannnya. Salah satu pendekatan terhadap dua pemrosesan sikap adalahcognitive respons theory. ${ }^{24}$ Teori ini menjelaskan bahwa perubahan sikap setelah menerima komunikasi persuasive akan tergantung pada respon kognitif seseorang. Cognitive respons theory menjelaskan bahwa perubahan sikap akan bergantung pada seberapa besar dan apa jenis counterarguing (argument yang berlawanan) yang muncul. Jika pesan menimbulkan argument kontra yang kuat dan efektif, maka kemungkinan besar tidak akan terjadi perubahan sikap. Sebaliknya, persuasi dapat dilakukan dengan mengintervensi proses kontra-argumen tersebut. Jika seseorang tidak menemukan argument yang cukup kuat untuk menentang pesan itu dan tidak bisa focus pada pesan saat mendengarkannnya, maka kemungkinan besar dia akan menerima dan mendukung pesan itu. Penerimaan ataupun perubahan terhadap sikap terhadap ide penegakkan khilafah Islamiyah dapat dijelaskan dengan Cognitive respons theory

\footnotetext{
${ }^{23}$ Cherry, K. What is a heuristic? http://psychology.about.com/od/hindex/g/heuristic.htm.

${ }^{24}$ Taylor, dkk, Psikologi...h.178
} 
Petty dan Cacioppo membedakan anatar jalur utama (sentral) ke persuasi dan jalur pinggiran (periferi) ke persuasi ${ }^{25}$. Orang cenderung menggunakan jalur utama ini apabila mereka terlibat dalam suatu isu, ingin mendapatkan pemahaman yang tepat atau menyadari ada pihak lain yang ingin mengubah sikapnya. Adapun jalur pinggiran adalah jalur tanpa menggunakan pertimbangan dan pemikiran mendalam. Orang cenderung memproses pesan secara periferal apabila mereka tidak terlibat dalam isu, dipengaruhi oleh daya tarik konteks atau sedang memiliki banyak pikiran dan pekerjaan lain.

Pemrosesan pesan secara sentral atau peripheral ini akan mempengaruhi kemungkinan elaborasi pesannya, yakni apakah seseorang akan memikirkan persuasi komunikasinya secara mendalam atau tidak. Secara umum, seseorang akan melakukan elaborasi kognitif secara mendalam apabila mereka menggunakan rute sentral daripada menggunakan rute periferal.

Oleh karena itu penerimaan, atau perubahan sikap misalnya terhadap ide penegakkan Khilafah Islamiyah sangat dimungkinkan melalui jalur pemrosesan heuristik. Mengapa? Hal ini dapat dilihat dari karakteristik aktivitas atau kegiatan yang dilakukan oleh kelompok yang mengusung ide penegakkan Khilafah Islamiyah ini. Misalnya nara sumber yang ditampilkan pada kampanye atau pawai adalah yang memiliki daya pikat tertentu baik karena kepopulerannya atau karena keahliannya. Pesan dilakukan dengan argument yang panjang dan menggunakan pesan melalui video. Aktivitas berjalan dengan target adanya keterlibatan respon audiens serta setting audio visual yang penuh perencanaan matang. Kondisi yang disebutkan di atas merupakan kondisi yang mendukung pemrosesan heuristik sebagaimana yang dijelaskan oleh Taylor dan kawan-kawan. ${ }^{26}$

Penelitian ini juga mendukung pendapat para pakar sebagaimana yang dijelaskan oleh Wahyudin bahwa selain pemaknaan diri, remaja yang lebih mudah terkena paham radikal adalah remaja yang tidak terbiasa berpikir kritis atau berpikir rasional komprehensif. Remaja yang rentan dengan ideologi radikal umumnya memiliki pengalaman hidup terbatas,

\footnotetext{
${ }^{25}$ Jalur peripheral ini oleh Shelly Chaiken disebut dengan istilah heuristic processing yaitu memproses informasi secara cepat dan efisien dengan menggunakan jalan pintas atau kaidah umum untuk mereduksi problem kompleks menjadi problem yang dapat ditangani dengan sederhana.Taylor dkk., Psikologi, ...., ibid., h.179-180

${ }^{26}$ Ibid. h. 179
} 
relasi sangat sedikit, pengalaman ketidakadilan, pengalaman tidak dimanusiakan, kegagalan hidup, atau tinggaldalam lingkungan yang homogen.Keterbatasan itu membuat mereka cenderung berpikiran tertutup sehingga sulit berpikir kritis. ${ }^{27}$

Penelitian ini juga menunjukkan kesimpulan yang sama dengan penelitian Lutfi. Salah satu hasil penelitian Lutfi pada 814 mahasiswa UIN Jakarta adalah bahwa kekecewaan tidak memberi pengaruh secara langsung terhadap munculnya radikalisme, tetapi pengaruhnya diperantai oleh variabel self esteem ${ }^{28}$.Dengan demikian kekecewaan dan persepsi terhadap situasimasyarakat dan bangsa tidak serta merta mempengaruhi seseorang untuk bersikap radikal. Sejumlah variabel perantara mempengaruhi hubungan antara keduanya.Hal ini juga menjelaskan mengapa terjadinya bervariasi sikap individu terhadap ide radikalisme termasuk ide terhadap penegakkan Khilafah Islamiyah. Dengankata lain terdapat perbedaan individual dalam variabel motivasional dan kognitif yang dapat memediasi hubungan antara variabel persepsi dan munculnya sikap individu terhadap suatu obyek sikap termasuk ide penegakkan Khilafah Islamiyah di Indonesia.

\section{Kesimpulan}

Ada dua kutub cara berpikir manusia, yaitu cara berpikir sistematik (di beberapa literature disebut sebagai berpikir kritis) dan cara berpikir heuristik.Cara berpikir sistematik bercirikan pemikiran yang penuh upaya dan kehati-hatian, proses pemikirannya aktif, kreatif dan sadar.Saat seseorangdalam pemikiran sistematik sejumlah hal dianggap penting dan berpengaruh. Pemikir sistematik akan mencari argumen berupa fakta, bukti, contoh alasan dan logika. Seorang yang berpikir sistematik saat melihat, membaca atau mendengar ide tentang Khilafah Islamiyah baik dari teman, media massa atau orasi misalnya, pemikirannya asyik mempertanyakan apakah klaim tentang keharusan menegakan Khilafah Islamiyah itu didukung oleh nash Alquran dan Hadist, apakah orang atau media yang menyampaikannnya cukup kredibel, mengapa ada perbedaan pendapat tentang konsep Negara dalam Islam dan kewajiban

${ }^{27}$ Wahyudin, M.Zahid, Muda, Pintar dan Terjebak Radikalisme thttp://print.kompas.com/baca/2015/04/13/Muda\%2c-Pintar\%2c-, diunduh tanggal 17 Juli 2015

${ }^{28}$ Ikhwan Lutfhi., Buku Program dan Kumpulan Abstrak Temu Ilmiah Nasional dan Konferensi Ikatan Psikologi Sosial, Ikatan Psikologi Sosial Himpunan Psikologi Indonesia, 21-23 Janauari 2015, h. 106 
mendirikannya, dan seterusnya.

Di kutub lainnya, pemikiran heuristik bercirikan pemikiran yang sambil lalu, ambil jalan pintas, sadar atas situasi meskipun tidak cermat dalam menangkap kejanggalan, kesalahan dan kegamangan dari situasi.Pada pemikiran heuristik, argumen justru tidak dipandang penting, baginya Cues atau Pertanda berupa daya tarik,keakraban dan keahlian sumber lebih dipandang berharga. Seorang yang sedang menggunakan pemikiran heuristik saat bersentuhan dengan ide Khilafah Islamiyah, lebih tertarik pada lambang-lambang, jargon dan kesimpulan singkat, cepat dan memuaskan tentang apa dan mengapa Khilafah Islamiyah itu, setelah itu menutup diri untuk memperhatikan argumen lain.

Namun demikian, sikap setuju seseorang terhadap ide penegakkan Khilafah Islamiyah memudahkannya didorong untuk melakukan tindakan-tindakan tertentu untuk terwujudnya ide tersebut. Keadaan ini bisa mengantarkan seseorang untuk melakukan prilaku memaksa, intoleran dengan kelompok yang tidak menerima ide dan mungkin juga melakukan tindakan kekerasan. Artinya sikap radikal pada tataran wacana sangat mungkin membawa kepada level aksi dimana sikap radikal diwujudkan dengan melakukan aksi-aksi kekerasan atas nama agama, seperti yang dijelaskan oleh Sangsoko dengan mengutip pendapat Singh dan Mulkhan.

Di sisi lain generasi muda secara psikologis masih berupaya mencari identitas diri dan motivasi hidup. Motivasi untuk hidup yang lebih baik, membuat generasi muda rentan menerima paham-paham radikalisme. Sangsoko menjelaskan bahwa lingkaran kelompok dengan ajaran-ajarannya memberikan pengaruh terhadap perilaku anggotanya terutama generasi muda dengan cara melalui dialog, dakwah, dan menanamkan ajaran-ajaran radikal yang secara terus menerus dituntun sehingga tercipta persepsi bahwa kehidupan bernegara sekarang harus diubah dengan sistem sesuai dengan ajaran-ajaran Islam radikal karena mereka berkeyakinan bahwa dengan perubahan sistem tersebut akan menciptakan kehidupan yang lebih baik.

Sikap terhadap penegakan Khilafah Islamiyah oleh kelompok Islam politik, menurut Effendy didorong oleh kecenderungan untuk memahami Islam secara literal. ${ }^{29}$ Selanjutnya Muluk dan Sumaktoyo, menjelaskan individu atau kelompok yang memahami agama secara literal

${ }^{29}$ Chusniyah, T, Model...h. 73 
ini memiliki struktur kognitif yang sederhana dan berfikiran tertutup. ${ }^{30}$ Tidak dapat menghadapi kepercayaan/pandangan lain yang berbeda. Oleh karena itu, apa yang diyakininya sebagai kebenaran absolut dan tidak dapat dipertanyakan, serta melihat ideologi alternatif sebagai salah secara absolut. Keadaan ini semakin terdukung oleh tingkat kebutuhan untuk menolak ketidakpastian.

Pendapat para ahli di atas dan hasil penelitian ini menunjukkan pentingnya pengembangan berpikir kritis bagi generasi muda, bahkan sejak usia dini. Pola berpikir seseorang terbentuk berdasarkan pengalaman pengasuhan orang tua, guru, masyarakat dan di perguruan tinggi (dimana proses perkuliahan, interaksi akademis dosen dan mahasiswa) semuanya menjadi factor-faktor yang mempengaruhi bagaimana pola berpikir mahasiswa terbentuk dan berkembang. Pengembangan berpikir kritis pada generasi muda menjadi salah satu cara untuk menyiapkan generasi mudamenjadi pribadi yang selalu kritis terhadap situasi dan lingkungannnya. Kemampuan berpikir kristis memungkinkan generasi mudamemiliki pemikiran yang komperhensif untuk memahami benturanbenturan ide di sekitarnya, membuat kesimpulan dan menemukan solusi masalah berdasarkan alasan yang kuat dan yang palinng penting membiasakan diri untuk berpikiran terbuka.

Oleh karena itu, sudah seharusnya perguruan tinggi khususnya perguruan tinggi Islam mengembangakanmetode pembelajaran yang kritis di kelas. Diskusi terbuka, debat dan sikap mempertanyakan sesuatu (ide, pikiran, keputusan dan lain-lain) merupakan wahana penting untuk mengembangkan cara berpikir kritis. Di samping, perlunya mata-mata kuliah tertentu seperti Perbandingan Mazhab, Ushul Fiqh, Perkembangan Pemikiran dalam Islam dan yang sejenis, menjadi mata kuliah yang dapat menempa mahasiswa untuk memahami diferensiasi pemikiran.

\footnotetext{
${ }^{30}$ Ibid
} 


\section{DAFTAR PUSTAKA}

Baron, R.M., \& Kenny, D.A., 1996,"The Moderator-mediator Variable Distinction in Social Psychological Research Conceptual, Strategic, and Statistical Consideration',Journal of Personality and Social Psychology, 51, 1173-1182

Cherry, K. 2012. What is a heuristic? Diunduh darihttp://psychology.about.com/od/hindex/g/heuristic.htm. Tanggal 8 Desember 2014

Chusniyah, T, 2012,"Model Sikap terhadap Penerapan Khilafah-Syariah di Indonesia', INSAN,14 No. 02, 63 -83

http://hizbut-tahrir.or.id/2014/10/28/icms-indonesia-congress-of-muslimstudent. Diunduh tanggal 10 Desember 2014

http://hizbut-tahrir.or.id/2014/12/02/khilafah-vs-nation-state/. Diunduh tanggal 27 Oktober 2016

Kahneman, D. 2002. Maps of bounded rationality: A perspective on intuitive judgment and choice.Diunduhdari http://www.nobelprize.org/nobel prizes/economics/laureates/2002/k ahnemann-lecture.pdf. tanggal 10 Desember 2014

Khairiri, Ahmad, 2014.Gerakan fundamentalisme di Perguruan Tinggi Islam (Studi pada Gerakan dan Strategi Kaderisasi HTI di Kampus UIN Syarif Hidayatullah Jakarta). “Skripsi”, Jakarta :UIN Syarif Hidayatullah

Lutfi, Ikhwan. Buku Program dan kumpulan abstrak temu Ilmiah nasional dan Konferensi Ikatan Psikologi Sosial, Ikatan Psikologi Sosial Himpunan Psikologi Indonesia, 21-23 Janauari 2015

Moghaddam, F. M, 2015,"Staircase to Terrorism: A Psychological Exploration'. American Psychologist, 60(2), 161-169, DOI: 10.1037/0003-066X.60.2.161

Myers, David.G.,2012, Psikologi Sosial. Penerjemah Aliyah Tusyani dan kawan-kawan., Jakarta: Salemba Humanika

Milla, M.N. (2008), "Bias Heuristik dalam Proses Penilaian dan Pengambilan Strategi Terorisme',Jurnal Psikologi Indonesia, 1, 921., 
Peran Pemißiran Heuristikpada Hu6ungan Persepsi Sosial dengan Munculnya Sikap terhadap Ide Penegakkan Khilafah Islamiyah di Indonesia Nurjannnah, 2013, Radikal vs Moderat: Atas Nama Dakwah, Amar Makruf Nahi Mungkar dan Jihad. Yogyakarta: Aswaja Pressindo

Sarwono, S.W.,1999, Psikologi Sosial. Jakarta: Balai Pustaka

Sklad, M \& Diekstra, R.,.2014,"The Development of The Heuristic and Biases Scale' (HBS), Procedia Social and Behavioral Sciences, 112 , 710-718

Taylor, Shelley,E., Peplau, L.A.,Sears, David O., 2009, Psikologi Sosial. TerjemahanTri Wibowo B.S. Jakarta: Kencana Pernada Media Group

Wahyudi, M.Zaid Muda, Pintar, dan Terjebak Radikalisme diunduh dari http://print.kompas.com/baca/2015/04/13/Muda\%2c-Pintar\%2cdan-Terjebak-Radikalisme tanggal 13 April 2015 